\title{
Interação e convergência midiática: storytelling no comercial da Apple*
}

\author{
Eliane Meire Soares Raslan** \\ Gabriel Guilherme Ferreira*** \\ Recibido: 2020-07-02 • Enviado a pares: 2020-07-28 \\ Aprobado por pares: 2020-08-29 • Aceptado: 2020-09-08 \\ https://doi.org/10.22395/angr.v19n38al1
}

\begin{abstract}
Resumo
Este trabalho é resultado parcial do Grupo de Estudos Prolim - Processos e Linguagens das Imagens Mídias - CNPq, teve como objeto principal de estudo a trilha sonora do comercial natalino de 2018 da Apple, intitulado Share your gifts ("Compartilhe seus presentes"), a partir da qual se realiza uma análise de sua interação midiática com o consumidor a partir da produção e da distribuição no storytelling. A utilização do formato de storytelling em seu comercial natalino de 2018 empregou uma trilha sonora que é destacada como conexão emocional entre a marca e o sujeito, o que contribui para suas relações de mercado, algo que nos leva a verificar a interferência e atenção gerada nos interlocutores a partir da trilha sonora usada. Com base no método de análise do discurso, analisamos o referido comercial e verificamos a forma como os interlocutores transmitem a mensagem intervém diretamente na história contada pela empresa; desse modo, é necessária a compreensão das técnicas usadas do storytelling na campanha, como também as práticas midiáticas e mercadológicas para fortalecer a marca e influenciar diretamente na relação entre sujeito e meios de comunicação. Nesse intercâmbio dos meios de comunicação, também levamos em consideração as questões emocionais — presentes nessa trilha sonora do storytelling —, que fazem parte da tendência comunicacional globalizada; ao mesmo tempo, verificamos a mensagem em seu formato de divulgação que se destacada entre as grandes marcas e suas influências midiáticas. Apreendemos que o uso do storytelling se tornou um dos meios de convergências comunicacionais das grandes marcas, as quais tendem a focar a interação midiática com o sujeito e alavancar o seu posicionamento no mercado, a partir deste novo formado de consumidor, que se torna o porta voz da divulgação online - um consumidor ativo, influenciando diretamente nestas mediações das mensagens.
\end{abstract}

Palavras-chave: consumidor ativo; meios de comunicação; mediação na Internet; relações no storytelling; trilha sonora.

Resultados do Grupo de Pesquisa Prolim - Processos e Linguagens das Imagens Midiáticas CNPq, vinculado ao Centro Cepccom - Centro de Editorações, Publicações e Criações em Comunicação da UEMG - Universidade do Estado de Minas Gerais, Unidade Divinópolis, Estado de Minas Gerais, Brasil. Apoio: Edital PAPq 01/2019UEMG

. Doutora em Comunicação Social. Universidade do Estado de Minas Gerais (UEMG). Brasil. Professora e pesquisadora da UEMG, Unidade Divinópolis, Minas Gerais. Líder do grupo de estudo Processos e Linguagens das Imagens Midiáticas-Conselho Nacional de Desenvolvimento Científico e Tecnológico, Brasil. Editora da Revista de Comunicação fandom - Jornalismo \& Publicidade. Apoio: Edital 01/2019 PAPq-UEMG. Link: https://cepccomuemg.wixsite.com/cepccom. E-mail: eliane.raslan@uemg.br Orcid https://orcid. org/0000-0002-2274-2836

... Estudante de graduação no curso de Comunicação Social, Publicidade e Propaganda da UEMG.Universidade do Estado de Minas Gerais, Brasil. Membro do grupo de estudo Processos e Linguagens das Imagens Midiáticas-Conselho Nacional de Desenvolvimento Científico e Tecnológico, Brasil. E-mail: gabrielgferreira@icloud.com Orcid https://orcid.org/0000-0002-2349-6868 


\title{
Interacción y convergencia de medios: storytelling en Apple commercial
}

\begin{abstract}
Resumen
El presente trabajo es un resultado parcial del Grupo de estudio Prolim - Procesos e idiomas de las imágenes de los medios - CNPq, cuyo principal objeto de estudio es la banda sonora del comercial navideño de 2018 de Apple, titulado "Share Your Gifts" - traducción "Comparte tus regalos", analizando la interacción de los medios con el consumidor desde la producción y distribución en storytelling. El uso del formato Storytelling en su comercial navideño de 2018 empleó una banda sonora que se destaca como una conexión emocional entre la marca y el sujeto, lo que contribuye a sus relaciones con el mercado, algo que nos lleva a constatar la interferencia y atención que se les presta a nuestros interlocutores desde la banda sonora utilizada. Comenzamos con el método de análisis del discurso, comprobamos a través del análisis de este video que la forma en que los interlocutores transmiten un mensaje interviene directamente en la historia contada por la empresa, de esta manera, nos damos cuenta de que es necesario entender las técnicas utilizadas en storytelling en la campaña, así como las prácticas mediáticas. y marketing para fortalecer la marca, influencia directa en la relación entre sujeto y medio. En este intercambio de medios de comunicación también se tienen en cuenta cuestiones emocionales, presentes en esta banda sonora de la narración, que forma parte de esta corriente comunicativa globalizada; al mismo tiempo, verificamos el mensaje en su formato de difusión que destaca entre las grandes marcas y sus influencias mediáticas. Entendemos que el uso del storytelling se ha convertido en uno de los medios de convergencia comunicacional de las grandes marcas, tienden a enfocarse en la interacción mediática con el tema y apalancar el posicionamiento de estas marcas en el mercado, además se descubrió que el consumidor actual también se ha convertido en el portavoz de la difusión en línea, un consumidor activo que influye directamente en estas mediaciones de mensajes.
\end{abstract}

Palabras clave: medios de comunicación; mediación en internet; difusión de la cultura; relaciones en la narración; banda sonora y consumidor.

\section{Interaction and Media Convergence: Storytelling in Apple Commercial}

\begin{abstract}
This work is a partial result of the Prolim Study Group - Processes and Languages of Media Images - CNPq, qualitative research whose main object of study is the soundtrack of the 2018 Christmas commercial from Apple, entitled "Share Your Gifts", analyzing your media interaction with the consumer from the production and distribution in storytelling. The use of the storytelling format in his 2018 Christmas commercial, employed a soundtrack that is highlighted as an emotional connection between the brand and the subject, which contributes to their market relations, something that leads us to verify the interference and attention generated in the interlocutors from the soundtrack used. We started with the discourse analysis method, we verified through the analysis of this video that the way the interlocutors transmit a message intervenes directly in the story told by the company, that way, we perceive the need to understand the techniques used by storytelling in the campaign, as well as media and marketing practices to strengthen the brand, direct influence on the relationship between subject and means of communication. In this exchange in the means of communication, we also take into account emotional issues - these present in this storytelling soundtrack, which is part of this globalized communication trend; at the same time, we verify the message in its dissemination format that stands out among the big brands and their media influences. We realize that the use of storytelling has become one of the means of communicational convergence of major brands, they tend to focus on media interaction with the subject and to leverage the positioning of these brands in the market, it was found that the current consumer has also become the spokesperson for online dissemination - an active consumer, directly influencing these mediations of messages.
\end{abstract}

Keywords: means of communication; internet mediation; cultural diffusion; relationships in storytelling; soundtrack and consumer. 


\section{Introdução}

O grupo de estudo Processos e Linguagens das Imagens Midiáticas (Prolim), cadastrado pelo Conselho Nacional de Desenvolvimento Científico e Tecnológico tem o intuito de registrar as novas linguagens midiáticas e como as imagens contribuem para a interação dos grupos que navegam na internet. Logo, este estudo é um resultado parcial das pesquisas do Prolim, com o propósito de explicar o comportamento das grandes marcas a partir do uso dos meios midiáticos e como as novas convergências midiáticas usadas por elas vêm alterando o comportamento da sociedade. Desse modo, nossa abordagem foi definida numa pesquisa qualitativa, sendo que o cenário analisado foi a internet, tendo como objeto de investigação a trilha sonora do comercial natalino da empresa Apple (2018). Embasamo-nos no método de análise do discurso (AD), verificando a materialidade e a configuração comunicacional existentes no comercial da Apple, as técnicas comunicativas e a emoção musical presente em forma de discurso tanto no áudio quanto no visual. Assim, percebemos que a marca utiliza de planejamento e de conceitos da propaganda apresentados na linguagem midiática da internet. Desse modo, possibilitou-se uma pesquisa explicativa que identificasse as ocorrências relacionais que contribuíssem para a aceitação do vídeo da marca Apple. Ao analisarmos a interação do público online com o vídeo - disponível na plataforma do YouTube, nos levou a perceber o envolvimento de sensações e de sentimentos entre sujeito e marca. Os dados obtidos foram gratificantes e nos despertou para as diversas percepções quanto às novas convergências midiáticas utilizadas pelas grandes marcas. Neste estudo temos a trilha sonora do comercial natalino da empresa Apple (2018) como objeto de pesquisa, embasamo-nos no resultado do envolvimento emocional do sujeito e da marca a partir do storytelling na plataforma de compartilhamento de vídeos do YouTube, numa interpretação a partir da AD.

Como foco principal da trilha sonora do comercial natalino de 2018 da Apple, analisamos a influência musical no processo de interação midiática com o consumidor, a partir da produção e da distribuição no storytelling. Nesse contexto, observamos como as marcas buscam comunicar com o público para envolvê-lo, além do intuito mercadológico de venda, usufruindo de elementos publicitários nas mensagens cada vez mais globalizadas. A análise da interação dos meios de comunicação apoia-se também em um julgamento das emoções presentes em trilhas sonoras. Nesse sentido, como o storytelling faz parte da tendência comunicacional globalizada, verificamos que a mensagem em seu formato de divulgação se destaca entre as grandes marcas e suas influências midiáticas, além de ser um caminho de interação midiática com o consumidor. Com isso, levantamos alguns questionamentos. A trilha sonora pode interferir nas reações do ouvinte? Considerando que o storytelling é uma 
linha para as relações entre marcas, clientes e meios de comunicação, a escolha da trilha sonora pode interferir na geração de sentidos da narrativa? Então, qual o contexto deve ser traçado na escolha da trilha sonora? Verificamos que as narrativas apresentam maior chance de engajamento do público em função de publicidades corriqueiras, logo a escolha da trilha sonora deve estar presente na narrativa, possibilitando que o receptor entenda a mensagem, e consequentemente a empresa consiga captar a atenção do interlocutor.

As questões de pesquisa em torno do storytelling partem da nossa intenção em demonstrar sua eficiência na afirmação de uma das grandes marcas e tendo em vista que as escolhas musicais para sua implementação são pouco visibilizadas como meio de extrema importância na eficácia de suas campanhas publicitárias. Na era da globalização, na qual as marcas usam cada vez mais a narração na mídia para a venda e a divulgação de sua imagem, o storytelling vem sendo uma ferramenta utilizada com o intuito de promover marcas ou produtos em campanhas publicitárias. O alto número de acesso no site do Youtube (2018 a-e) ao vídeo de Natal de 2018, criado pela Apple, justificam a escolha da trilha comercial, narrativa usada que parte do representativo e atual quanto à contação de histórias, usada por grandes marcas para estabelecer vínculos com o consumidor. A modificação dos meios de comunicação em função do avanço tecnológico permite que novas ferramentas sejam desenvolvidas no que tange ao mercado e ao consumidor, a fim de criar formatos alternativos para criar um diálogo efetivo por meio das produções audiovisuais. Entretanto, com o público consumidor mais disperso devido ao próprio avanço tecnológico e comunicacional, as publicidades que aderem às narrativas apresentam maior índice de captação da atenção e da confiança do público, além de impulsionar o posicionamento da marca com a utilização de elementos simbólicos. Um exemplo é a narrativa somada à trilha sonora, além de proporcionar ambiência, contribui para a construção de sentidos. Portanto, há de se atentar às sensações que o storytelling deseja transmitir aos interlocutores, pois a sonoridade está intimamente ligada aos processos de significação. Logo, a trilha sonora do comercial da Apple será um ponto de análise para compreender a interação midiática com o consumidor a partir da produção e da distribuição em formato de narrativa. Nosso objetivo não é comercializar a Apple, já que seria necessário tratar diversos comerciais realizados pela empresa para julgarmos sua competência de comunicação com os seus consumidores, o que pode ser sugestão para novos estudos. Aqui se trata da análise específica de um vídeo de comercialização da Apple, sendo que apenas sua divulgação na plataforma do YouTube gerou uma quantidade enorme de visualizações e (inter)locutores, a partir do método de 
$\mathrm{AD}$, sendo uma das ferramentas que nos permite examinar a narrativa usada no vídeo, entre as diversas ações comerciais na atualidade, e a partir da AD, percebemos que a forma como os meios de comunicação vem sendo usados pelas empresas. A partir disso, questiona-se se as trilhas musicais podem auxiliar e dialogar com os consumidores e se eles passam a ser públicos ativos diante das grandes marcas.

Para justificar o recorte realizado neste trabalho, podemos recorrer à tese de doutorado de Luis Oliveira (2010), que aborda a emergência do significado em música, a qual deve ser observada com muita atenção. Analisa os processos de significação em música a partir do modelo fenomenológico e semiótico com conceitos teóricos na filosofia peirciana. Discute existir mudanças no pensamento ocidental que interferem no nosso olhar sobre a música e os significados que partem de nossa imitação da forma e do coletivo. Significados que também têm interferências psicológicas e de nossas expectativas musicais. Significações musicais que correspondem à emergência, à auto-organização e à criatividade, algo que relaciona diretamente o indivíduo à percepção deste novo formato tradicional de pensamento ocidental. Para sintetizar as visões do autor, é necessário entender a música enquanto sonora e harmônica, e que ela possui força para influenciar a conduta humana. A partir disso, fica evidente que o objeto destacado neste estudo, o comercial natalino da Apple de 2018, carrega essa ótica expressiva e que, através da música, prega um mecanismo que justifica sua construção:

não apenas refletem musicalmente um texto particular, mas podem representar a significação adotada em combinação com outros textos ou contextos não textuais. Da mesma maneira que o sermão falado deve ensinar e edificar o ouvinte, também a música poética deve pregar em vez de simplesmente entreter. (Bartel, 1997, p. 358)

O que nos leva a examinar a música utilizada no comercial da Apple, "Come out and play", da cantora Billie Eilish, logo buscamos as ideias do autor Luis Oliveira (2010), por tratar os movimentos diversos, como algo que parte da simpatia e por causar daquilo que estes movimentos supostamente carrega, ou seja, existe um processo de significação causado pela própria trilha, aquilo que ela significa e representa em seu discurso e letra, além destas questões, na música de Billie temos a relação que ela possui com a imagem e vídeo, o que sustenta o formato utilizado pela marca em seu comercial e cumpre seu papel em função do interlocutor, este último, partimos da ação narrativa desta música quanto a análise de discurso.

é de suma importância entender que a trilha sonora do comercial natalino de 2018 da Apple perpassa pela análise do contexto sonoro e visual, uma vez que o 
emprego da trilha sonora é totalitário durante todo o comercial da marca Apple e, somado a este comercial, existe uma assinatura da campanha a ser compreendida. Para entendermos a negociação audiovisual entre música, assinatura e narrativa dentro desse comercial, pode-se afirmar que, segundo Foucault (2005, p. 145), esse conjunto de discursos efetivamente pronunciados é denominado de "arquivo". A pesquisadora Gregolin (2003) afirma que a proposta de Foucault (2005) sobre o arquivo engloba uma investigação de como ocorre a produção do discurso, como ele se dá no fazer histórico-social e como se insere e produz sentidos:

A análise do discurso propõe, portanto, descrever as articulações entre materialidade dos enunciados, seu agrupamento em discursos, sua inserção e formações discursivas, sua circulação através de práticas, seu controle por princípios relacionados ao poder, sua inscrição em um arquivo histórico. (Gregolin, 2003, p. 12)

Somada a isso, a sonoridade está intimamente ligada ao desenvolvimento visual e à narrativa em questão. A condução musical no comercial construída pela música "Come out and play", da cantora Billie Eilish, acontece com a união entre a letra musical, a assinatura da campanha e a narrativa, que atuam como elementos que elevam a emoção e a atenção do interlocutor. É possível, então, entender as variantes nos parâmetros sonoros em função do discurso musical e a narrativa, além de como ocorre a negociação entre eles para que a harmonização da campanha se conclua como efetiva, trazendo as sensações certas e o sentimento de pertencimento como personagem da narrativa para os interlocutores.

Foucault (2005) e Gregolin (2003) nos permitem verificar o quanto a materialidade anunciada no comercial da Apple nos leva a relacionar as mudanças comunicacionais ao poder da marca, à conexão emocional e às alterações nas mensagens da mídia. Neste estudo, é possível observar as mudanças sociais e publicitárias, e como estão relacionadas entre si em uma realidade de conexão que, até então, não era possível. Essas mudanças são compreensíveis quando vemos os comportamentos tanto das marcas quanto do público sendo configurados de forma mais interativa, humana e coletiva. Existem artifícios elencados na construção da narrativa e, para entendê-los aprofundamos na mídia e no consumido, buscamos os estudos de Henry Jenkins, Joshua Green e Sam Ford (2014), que tratam das novas formas de comunicação e nos permitem levantar discussões em torno da relação e da interação do sujeito e dos meios de comunicação.

Os autores Jenkins, Green e Ford (2014) afirmam que uma sociedade conectada é produtora de significados, que essa nova configuração comunicacional e midiática leva a uma maior interatividade a partir do novo comportamento do público e 
das marcas. Diante das influências da trilha sonora, procuramos levantar alguns apontamentos dos estudos de Denis Moraes (1999). Assim como as tendências da comunicação global e da emoção gerada pela música com René Descartes (2005), por tratar da razão do homem e o discurso diante do método, como também as contribuições referentes à cultura da mídia com Lúcia Santaella (2003), nos permitindo refletir sobre a música diante das interferências da cultura midiática. Os autores Al Ries e Jack Trout (1987) quanto aos conceitos da propaganda e às influências da mídia a partir dos elementos publicitários na mensagem, e Kotler, Kartajaya e Setiwan (2017) com seus estudos de estratégias e planejamento organizacional. Todos esses autores abordam as marcas em diversos aspectos, não no seu sentido técnico, mas sim nos aspectos culturais. Nosso objetivo não é conceituar marca nem mídia, propaganda, marketing ou planejamento de empresas, e sim, verificar, a partir desses pensadores, como a comunicação funciona conforme o seu público ativo.

No primeiro momento, pretende-se entender as relações de produção e distribuição da marca com o sujeito (consumidor), diante do storytelling como ferramenta. Em seguida, analisamos a trilha sonora do vídeo comercial da Apple, a partir de sua conexão emocional comercial. Ambas com o objetivo de entendermos o uso da trilha sonora musical no storytelling, sendo que na análise, percebemos uma tendência global quanto ao uso das trilhas sonoras, conforme o embasamento dos autores usados. Tratou-se de um estudo analítico de base teórica, que parte da interpretação dos discursos usados no vídeo natalino da Apple. Por último, identificamos o storytelling como forma de divulgação da Apple, que nos mostrou que a mensagem publicitária pode influenciar e ser influenciada pelas marcas e como os indivíduos nas redes opinam e estes passam a ser o sujeito-divulgador.

Com as novas formas de comunicação on-line, entendemos que o uso do método de AD foi eficiente; contudo, consideramos que as questões midiáticas da linguagem cultural e da mensagem publicitária buscadas em estudos de alguns autores foram necessárias, evitando influências opinativas por parte da equipe de estudo do grupo Prolim, especialmente, ao analisar as reações dos interlocutores quanto a trilha sonora do comercial natalino de 2018 da Apple, na plataforma do YouTube. Ao partir para fatos relevantes que ocorrem no mercado, de modo geral, percebemos diversas questões, em especial, o destaque da trilha sonora que tem influência na reação do consumidor, bem como se, por esse motivo, as escolhas musicais devem ser levadas em consideração, já que são geradoras de vários sentidos na narrativa, nos levando a ponderar e discutir os reais motivos destas trilhas sonoras musicais produzidos no Storytelling da Apple. 


\section{Interação da marca e do sujeito: relação de produção e distribuição com o storytelling nos meios midiáticos}

Para tratarmos a mídia e o consumidor, buscando o autor Henry Jenkins (2008) para repensar a relação e a interação do sujeito nos meios de comunicação. Partimos da trilha sonora do comercial da Apple (2018), verificando esse formato de produção que posiciona no mercado como uma cultura atual: nesse caso, o storytelling, que possibilita a conexão comunicacional entre a marca e os consumidores interlocutores que garantem o sucesso do comercial. A partir disso, Jenkins (2008) considera ser uma condução à transformação das interações sociais. Desse modo, podemos interpretar que o uso do storytelling é uma ferramenta de comunicação que fortalece a relação entre o sujeito e a marca, porque ele se apresenta como um produto da convergência comunicacional, pois, segundo Jenkins (2008):

Por convergência, refiro-me ao fluxo de conteúdos através de múltiplas plataformas de mídia, à cooperação entre múltiplos mercados midiáticos e ao comportamento migratório dos públicos dos meios de comunicação, que vão a qualquer parte em busca das experiências de entretenimento que desejam. (p. 30)

Através desse entendimento, é possível observar que o consumidor interlocutor deixa de ser, a priori, passivo, como apenas receptor de conteúdos e passa a tomar uma posição de produtor, passando a colaborar diretamente para as transformações do meio comunicacional em que está inserido. Jenkins (2008) argumenta que o processo dessas transformações é sustentado por um tripé composto por três conceitos, sendo eles: convergência midiática, inteligência coletiva e cultura participativa. Esses pilares são um reflexo do atual paradigma comunicacional que gira em torno de como as formas de produzir comunicação são formas de poder, como o receptor está cada vez menos retraído e como a comunicação é multifacetada. O assunto de contar histórias e novas formas de comunicação é algo atual e vem sendo utilizado pelas empresas, tendo a trilha sonora e a relação dos consumidores com as marcas, modificando, já que o atual consumidor se torna um produtor, cliente e público ativo. Percebemos, a partir do autor, que fatores como a apresentação desse vídeo da Apple transformam o consumidor em um interlocutor. Além disso, esses fatores se encontram presentes nas redes e trazem à discussão avaliações sobre a qualidade da criação do vídeo, na qual há uma associação à vida real quanto à relação dos interesses e do compartilhamento dos indivíduos. A partir disso, ainda é possível se discutir sobre a qualidade ou o interesse pelos produtos da Apple, como o MacBook exibido na abertura, sugerindo que nossas vidas estão atrás dessa tela. Nesse contexto, o próprio consumidor passa a tratar nas redes sua opinião sobre os produtos comercializados pela marca Apple a partir do vídeo, o que o transforma em meio de produção publicitária, já que 
parte do comercial e de suas características narrativas está sendo debatida na web e, por consequência, seus produtos estão sendo divulgados.

A partir da trilha sonora presente na narrativa da Apple (figuras 1 e 2), destacamos a transformação do consumidor como interlocutor, que assume um papel ativo nesse novo contexto comunicacional, no qual é possível ter voz diante de outros internautas. É possível perceber como a música permite que o consumidor se transforme em produtor e interlocutor, desde que ele tenha conhecimento prévio e faça assimilações com a publicização de conteúdo, ideias e opiniões narradas no comercial, para ter voz ativa diante de outros consumidores nas redes em função desse formato de divulgação.
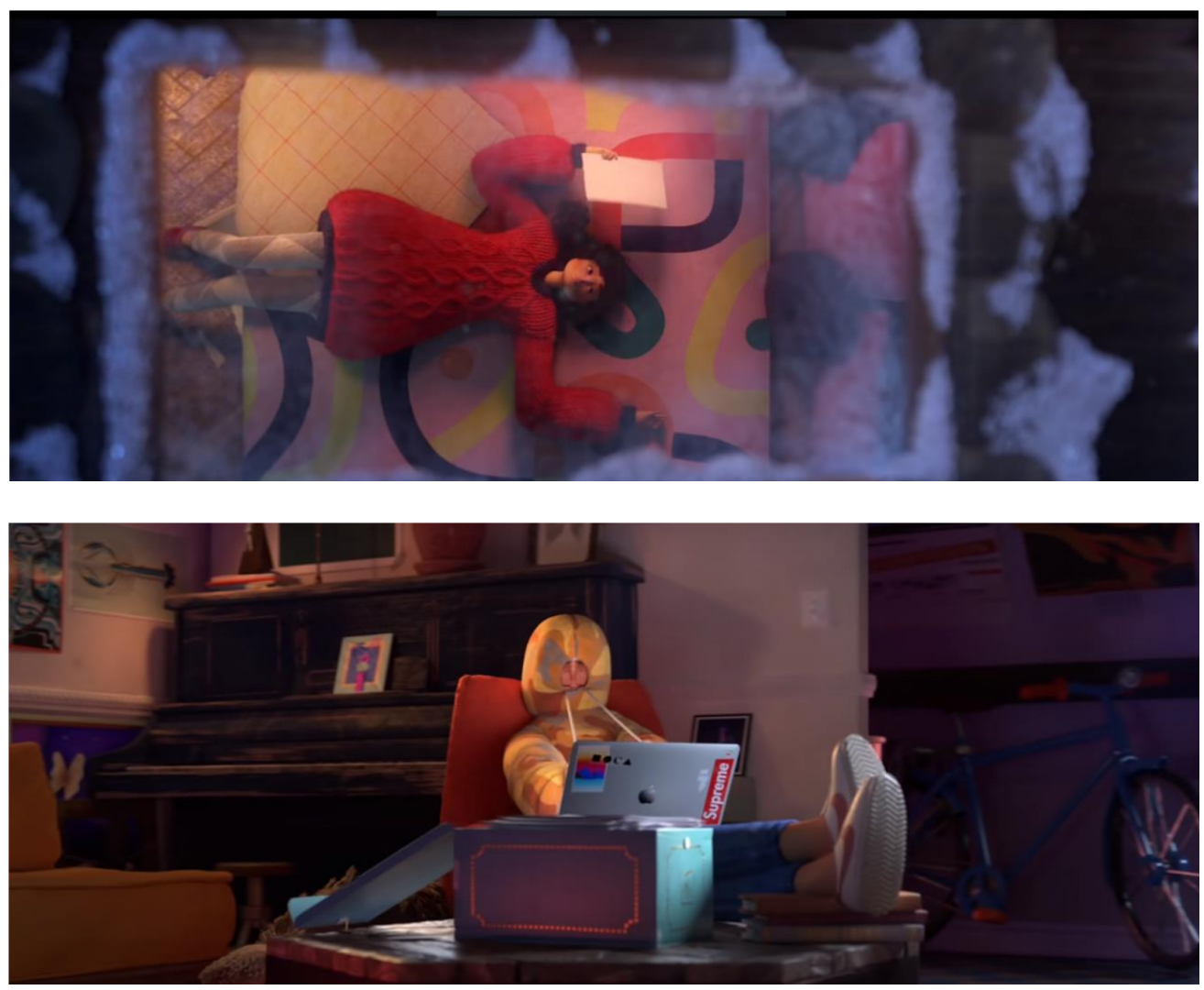

Figuras 1 e 2. Cenas do comercial da campanha natalina da Apple Share your gifts (2018)

Fonte: Trecobox. https://trecobox.com.br/2018/1 1/22/novo-comercial-de-natal-da-apple-promete-tocar-seucoracao/.

Adotar o formato de storytelling é confirmar que narrar uma história é algo culturalmente legitimado enquanto questão social. Temos uma tendência a darmos 
atenção para histórias desde pequenos, comportamento comum, que, no caso do comercial da Apple objeto deste estudo, engloba a melodia, independentemente do país, já que não utiliza de falas; é a trilha sonora que interfere em nossas compreensões e reações quando assistimos ao comercial. Na definição de Nuñez (2009), quanto às histórias, ele diz que "uma história é uma ferramenta de comunicação estruturada em uma sequência de acontecimentos que apelam aos nossos sentidos e emoções" (p. 26). Isso cruza com o que Signorelli (2011) profere sobre uma narrativa, em que existe um personagem que passa por conflitos ou obstáculos para que possa atingir seu objetivo. Dessa forma, fica fácil entendermos e traçarmos os pontos-chave do comercial, buscando identificar o que a marca Apple quis transmitir acerca da construção do seu comercial a partir dos meios midiáticos. Nesse contexto, a utilização do storytelling capacita o consumidor a virar o interlocutor do comercial e gera uma interação entre sujeito e marca, um envolvimento integrado e dinâmico que o leva a assumir uma realidade de forma natural perante os significados e valores que a marca carrega em função do público. Isso com o objetivo de se tornarem marcas mais funcionais e acolhidas na sua distribuição pelos receptores, uma estratégia baseada no mercado cultural de novos interesses.

O storytelling é a própria narrativa histórica e vem sendo comum nas diversas áreas como meio de interação com os indivíduos nas redes. Flórez-Aristizábal et al. (2019) verificaram que storytelling é uma ferramenta de transformação digital e serve como narrativa digital para auxiliar no ensino, dentro deste pensamento, analisando o storytelling da Apple, podemos considerar que os contos narrados envolvem o sujeito, são colaborativos e o levam à motivação. Ainda, com base nos estudos do autor, também pode ser inclusivo, já que é adaptado conforme os sujeitos envolvidos, isto é, seu processo de criação (design) que ocorre para o seu público.

Os avanços científicos estão cada vez mais debatendo sobre as tecnologias de comunicação e como elas servem de incentivo à educação e ao desenvolvimento social, além de possibilitar que os profissionais se tornem os condutores de histórias. Nesse sentido, Pombo-García (2015) afirma que storytellers partem da informação e que inovam e incentivam a ciência, além de divulgar informação, evitando sensacionalismo e ajudando o jornalismo. Com o storytelling, é possível fazer conexões a partir da mídia social, por meio da qual o público pode entender melhor suas pesquisas. Nesse contexto, pretende tornar as pesquisas confiáveis e alcançar uma comunicação científica, além de capturar a imaginação e a curiosidade de novas mentes. Nessa perspectiva, o storytelling não é apenas uma ferramenta de publicidade das empresas, mas também uma forma de interação com o indivíduo para informar e gerar opiniões nas redes, como podemos constatar neste estudo. 
Nesse comercial natalino da Apple (figuras 1 a 7), existem pontos importantes que queremos levantar com base no estudo de Nuñez (2009), ao tratar das histórias, porque a história contada nele vai além dos acontecimentos descritos, da própria questão significativa. A narração consegue se relacionar com pessoas diversas e ser entendida elas porque nela estão em completa harmonia os elementos visuais e os sonoros. Ainda de acordo com o autor (2009):

Uma boa história tem cheiro, textura, pode ser visualizada mesmo que não tenha um suporte visual, pode ser ouvida mesmo que seja muda e está repleta de sabores. Uma história verdadeira pulveriza a resistência do mais cínico e mal-humorado cidadão da Economia da Atenção. (p. 25)

Assim, o caminho traçado pela marca para a construção do comercial é sistematicamente estratégico, porque a marca busca epilogar uma essência. Gomez (2009) diz que essa essência é um atributo básico de uma marca autêntica e única, então podemos inferir que o próprio comercial em sua narrativa é um reflexo dos valores que a marca cultiva e o que ela tem a oferecer, no que tange ao indivíduo como centro desse processo. Processo de humanização muito bem exposto por Kotler, Kartajaya e Setiwan (2017), porque funciona como uma troca entre a marca e os artifícios que ela mesma usa para gerar uma personalidade a ela; a partir disso, torna-se parte do mercado junto ao público interlocutor para ser posto em xeque o consumo, visto que ele está atento aos conteúdos recebidos e agora com um poder crítico mais aguçado, devido à quantidade de dados diários que trocam com a rede junto à própria convergência dos meios de comunicação. É notório também que, com a utilização dessas ferramentas estratégicas publicitárias, o cenário mercadológico não está sofrendo mudanças sozinho, mas também a própria cultura do consumo e da produção, em face do novo posicionamento que as marcas vêm aderindo, indica um descortinamento na relação com o público interlocutor e consequentemente consumidor. O atual consumidor participa do processo de divulgação das marcas, interage e opina sobre o modo como estão sendo produzidas e distribuídas as mensagens em torno da marca. Nesse contexto, o storytelling influencia diretamente nas relações da marca com o sujeito. Logo, as músicas escolhidas para os storytelling interferem nessas relações e geram valores conforme as interações dos interlocutores envolvidos - temos uma "mensagem participativa".

Jenkins (2008) e Green e Ford (2014) argumentam que o indivíduo pertencente ao público interlocutor consumidor, após receber as mensagens da mídia, executa ações que remodelam o próprio cenário da mídia. Devido a esse fato, os autores também levantam em seus estudos o que se pode chamar de "mensagem participativa". O storytelling atua como uma mensagem em forma de convite para que o público possa interagir com o conteúdo na condição de atribuir novos significados e valores a 
partir do que está sendo distribuído a ele. A partir dessas interações, a construção da narrativa perpassa pelo conceito de alfabetização virtual, observado por Jenkins (2009). Dentro desse conceito, participamos das histórias e das experiências culturais não só como interlocutores influenciados, mas também como influenciadores. Essa troca de mensagens multimídias arquitetam uma conectividade que permeia o público e as práticas estratégicas.

Ocorre uma interação do público interlocutor consumidor com a mídia e o produto dela. Assim, o storytelling interfere na difusão dos significados criados e recebidos, pois se trata de uma construção estratégica das narrativas, com "uma mudança de 180 graus na natureza das relações entre consumidores e marcas. Cada vez mais, a 'propriedade' da marca é passada ao consumidor" (Batey, 2010, p. 16). O comercial da Apple utiliza o próprio consumidor como meio de produção publicitária. Esse sujeito interlocutor absorve a produção num processo de relação entre marca e sujeito, o que gera novos processos de divulgação na internet.

Percebemos, então, o que a dinâmica da interação da mídia e do consumidor causa nas práticas comunicacionais, levando essa relação de produção e distribuição do storytelling para muito além das redes sociais, já que as interações envolvem a emoção destes diversos indivíduos envolvidos. Podemos buscar os estudos de Silva (2016) para explanar como isso acontece:

A reconfiguração do cenário comunicacional a partir da liberação do polo de emissão proporcionou a criação de plataformas cada vez mais desvinculadas de um ponto fixo de conexão e mais interativas. Ademais da competência tecnológica que propicia o diálogo entre os meios, houve a intensificação do interesse de interação por parte da sociedade, ao manifestar pensamentos, criações e interpretações, assumindo assim o controle das mídias. (p. 10)

Em seu estudo, Silva (2016) argumenta que "a arquitetura da informação direcionada aos dispositivos móveis abarca novas possibilidades narrativas" (p. 5). Através disso, é possível adentrar de fato em um campo comunicacional mais amplo e assim justificar o porquê de agora os sujeitos serem ativos em função dos processos comunicacionais. Nessa perspectiva, o conceito de "mobile storytelling" emerge ao tratar das mídias digitais móveis a partir da análise das perspectivas narrativas que se baseiam na personalização das relações e no processo comunicacional. Isso corrobora os estudos de Lemos (2007a) sobre os princípios que regem a cibercultura, sendo "a liberação da emissão, a conexão generalizada e a reconfiguração das instituições e da indústria cultural de massa" (p. 125). É notório que a produção e a distribuição das marcas têm interferência durante e após o seu processo, visto que esse novo formato cultural utiliza as redes de conexões midiáticas. O sujeito está 
na mídia e quer interagir com a marca e os outros consumidores; nesse sentido, os suportes tecnológicos permitem esse novo formato de relação: temos uma comunicação virtualizada que cria formatos de entretenimento.

Referente a music branding, Neto e Martins (2012) afirmam que, no ambiente comercial, a música tem influência no comportamento do consumidor. As marcas passam a verificar o quanto a música pode interferir na fidelidade e na decisão de compra do sujeito. Além de criar laços do sujeito com a marca, perceberam que a música está sendo utilizada pelos empreendedores atuais, pois revela a identidade da empresa e influência no comportamento do consumidor. Essas relações estão presentes no comercial da Apple (2018): "a música parte da sensação vivenciada pelo público em um momento de emoção e compartilhamento, que envolve marca e sociedade".

\section{Tendências da comunicação global e cultura midiática: a trilha sonora da Apple numa conexão emocional}

Com base nas ideias de Denis Moraes (1999) e em como as novas tendências da comunicação global estão interferindo nas escolhas das mídias e seus formatos na divulgação das marcas, iniciamos as discussões em torno das influências provocadas a partir da trilha sonora. Além disso, abordamos a emoção a partir da música fundamentados em René Descartes (2005), quando o autor trata da razão do homem e o discurso diante do método, nos leva a considerar que o comercial da Apple está sendo analisado a partir do pretexto humana e não apenas suas emoções, enquanto a cultura da mídia com os pensamentos de Lúcia Santaella (2003) está muito mais relacionada a inercia social, ao ser estabelecida pelos meios de comunicação diante da recepção de mensagens destes indivíduos envolvidos, nesta relação opinativa sobre o vídeo da Apple nas redes. Percebemos que a interação midiática do consumidor com a marca Apple parte não apenas da tendência do uso do storytelling — aprovada pelos consumidores —, mas também pela forma como a música causa emoção, possibilitando, a partir da sua construção, uma associação audiovisual. A peça audiovisual construída e colocada em questão neste estudo foi pensada estrategicamente no contexto natalino; para isso, utilizou a trilha sonora produzida pela cantora Billie Eilish, pelo fato da Apple perceber que a composição musical desta letra se encaixava em seu storytelling, conseguiu tratar os processos de significação que a marca buscou atrelar com as imagens e, assim, construindo uma narrativa direta com os indivíduos nas redes.

O uso do storytelling pelas grandes marcas tornou-se uma tendência. De acordo com Moraes (2001), a globalização incitou as marcas a adentrar numa lógica 
produtiva de modo a conectar pessoas e fazer com que elas produzam significados juntamente com as próprias marcas, as quais agora, além de revigorarem o modo de produção capitalista, também contribuem para criar uma hegemonia social e cultural. Moraes (2001) realiza um levantamento acerca das tendências comunicacionais e de como a mídia porta um poder simbólico no capitalismo, passando por essa alteração no paradigma que evolui direcionando o campo para um único lugar: as infotelecomunicações. Para o autor Moraes (2001):

As corporações de mídia e entretenimento exercem um duplo papel na contemporaneidade. O primeiro diz respeito à sua condição peculiar de agentes operacionais da globalização, do ponto de vista da enunciação discursiva. Elas não apenas vendem e legitimam o ideário global, como também o transformam no discurso social hegemônico, propagando visões de mundo e modos de vida que transferem para o mercado a regulação das demandas coletivas. A retórica da globalização intenta incutir a convicção de que a fonte primeira de expressão cultural se mede pelo nível de consumo dos indivíduos e coletividades. Como se somente o mercado pudesse aglutinar o que se convencionou chamar de organização societária. (p. 8)

Em razão disso, a marca que está por trás do objeto deste estudo, a Apple, caminhou exatamente para essa evolução, acompanhando as novas tendências e se aproveitando disso para concentrar e construir sua mídia audiovisual, a fim de atingir com mais facilidade os interlocutores. O comercial natalino é um produto que une o visual e o sonoro, justamente pelo fato de a mídia facilitar a interconexão das plataformas. A partir do que Moraes (2001) cita em seu estudo acerca da nova situação global midiática e consequentemente comunicacional, a marca buscou conduzir seu conteúdo apenas para um meio, a internet, e por meio dele conseguiu elencar elementos midiáticos estrategicamente elaborados para envolver seu público.

Com base nos estudos de Moraes (2001), podemos afirmar que as figuras 3, 4 e 5 a seguir representam o que a marca Apple (2018) utilizou de forma estratégica na construção da sua narrativa, com elementos que a própria mídia dispõe a partir do novo enquadramento do mercado. Em função do poder midiático, a Apple, em seu comercial, concentrou sua lógica em retratar de forma simbólica o indivíduo e seus sentimentos em uma narração conduzida pelas sensações causadas com a música, que é o ponto de destaque deste trabalho, além de tornar possível a marca fortalecer sua imagem em prol da nova relação produtiva e consequentemente cultural, visto que é uma tendência comunicar dessa maneira.

As reflexões levantadas a partir disso nos fazem pôr em xeque o autor Descartes (2005), o qual, em seus seus estudos sobre a razão do homem e suas emoções, possibilita-nos entender um pouco acerca do conhecimento do indivíduo e do 

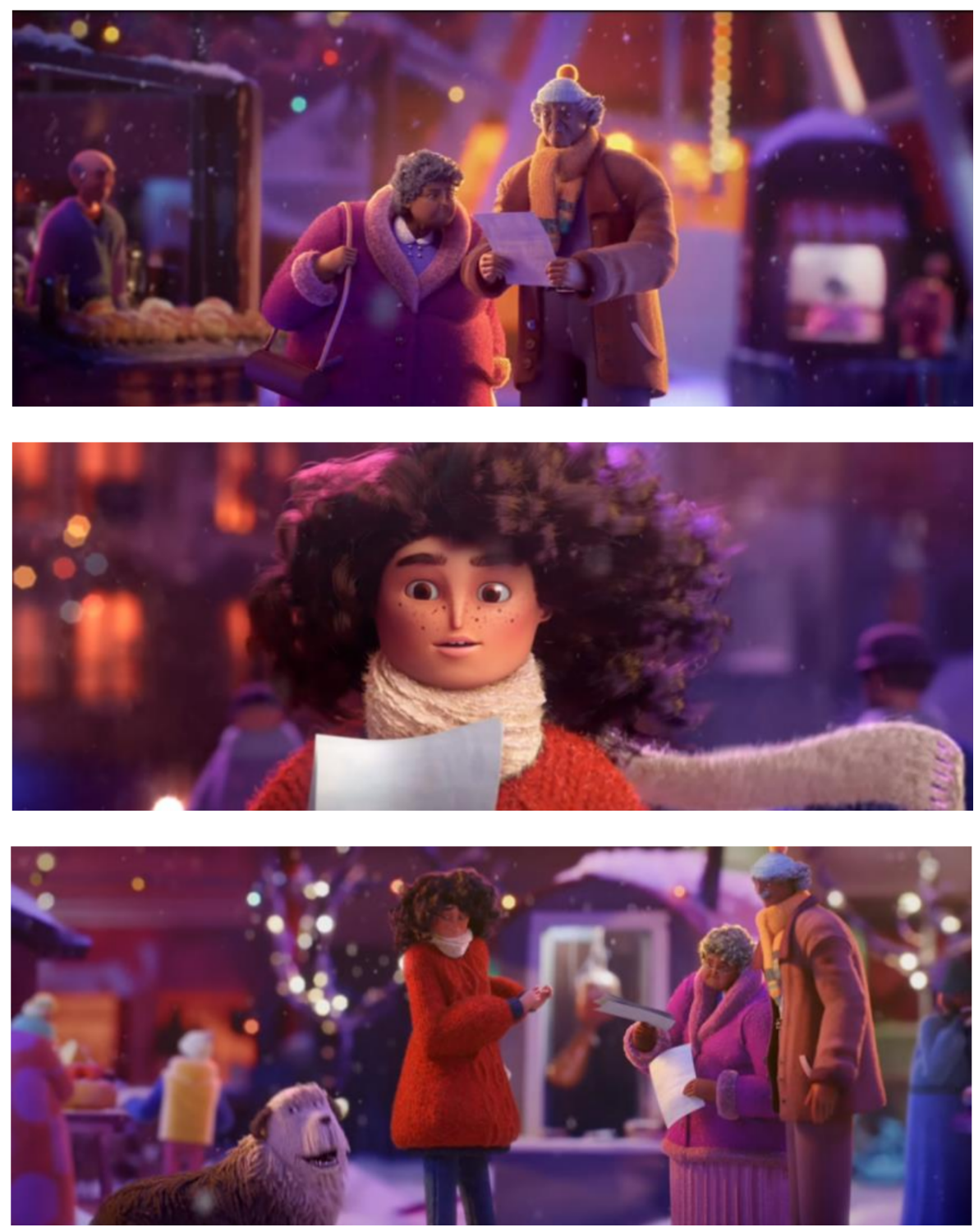

Figuras 3, 4 e 5. Cenas do comercial da campanha natalina da Apple Share your gifts (2018)

Fonte: Trecobox. https://trecobox.com.br/2018/1 1/22/novo-comercial-de-natal-da-apple-promete-tocar-seu-coracao/

próprio mundo. A narrativa desenvolvida pela Apple vai de encontro exatamente com o que esse autor tratou, pois, mesmo sendo um teórico do século XVII, suas ideias ainda se fazem atuais. Seu discurso sobre o método nos permite observar a trilha sonora atual enquanto influenciadora dos comportamentos dos indivíduos, ou seja, o que está sendo discursado na melodia é o que nos faz questionar o 
que é verdadeiro ou não, o que é real, como as coisas acontecem e como conduzimos a razão, tratando isso como uma necessidade ao invés de simplesmente nos envolver com o conteúdo. Essa teoria da razão nos leva a reflexões narrativas do comercial da Apple, já que se torna possível dizer que a projeção do pensamento do indivíduo é uma via dupla: por um lado, a marca busca arquitetar o que ela quer transmitir pela narrativa audiovisual com destaque na sonoridade, pois entende que a música faz parte da retórica do sujeito, podendo ordenar seus pensamentos; por outro, esse indivíduo parte de sua bagagem de conhecimento em busca do verdadeiro e, a partir do que sente com a narrativa, busca definir e realizar associações, temos um ordenamento dos pensamentos por parte da Apple, mesmo assim, não podemos desconsiderar que o conhecimento individual pode interferir na forma de recepção:

Eu estimava muito a eloquência e estava apaixonado pela poesia; mas acreditava que uma e outra fossem dons do espírito, mais do que frutos do estudo. Aqueles cujo raciocínio é mais ativo e que melhor ordenam seus pensamentos, com o intuito de torná-los claros e inteligíveis, sempre podem convencer melhor os outros daquilo que propõem, mesmo que falem somente o baixo bretão e nunca hajam aprendido retórica. (Descartes, 2005, p. 5)

Entretanto, fica claro que a marca pode e consegue interferir nesse processo de entendimento e significação, como mostra o autor. É possível que, a partir da visualização da narrativa, os indivíduos tomem o conteúdo como verdade incontestável e se moldem baseado nele. Além disso, a marca pode se aproveitar desse quadro para se oportunizar e conduzir os indivíduos a executar alguma ação, que pode ser mercadológica ou não, porque a mensagem transmitida na narrativa audiovisual não é apenas com o intuito de venda.

A escolha do objeto em questão - trilha sonora musical do comercial natalino da Apple (da figura 1 à 5) — se deu pela maneira estratégica em que foi construída a narrativa em um contexto no qual o processo de significação e geração de sentidos portam poderes simbólicos dando vida à marca e ao produto exibido, um MacBook, este disponível no mercado com preços mais baixos para nova geração de notebooks. Esse comercial é portador de inúmeros sentidos e significados que giram em torno do contexto natalino e da atual configuração comunicacional em que as marcas buscam criar vínculo com o público, a fim de estabelecer uma conexão com ele. É possível observar, no comercial, vários artifícios que justificam essa tentativa de aproximação da marca e a construção de valores e sentidos sociais como afeto, empatia, amor e sensibilidade, que são intimamente ligados à humanização da marca. Segundo Kotler, Kartajaya e Setiwan (2017): 
Cada vez mais, as marcas vêm adotando qualidades humanas para atrair consumidores na era centrada no ser humano. Isso requer descobrir as ansiedades e os desejos latentes dos consumidores por meio da escuta social, da netnografia e da pesquisa empática. (p. 172)

Contar histórias não é algo fácil para uma marca imersa em um cenário em que os interlocutores possuem tanta voz, principalmente na internet, cujo ambiente abre várias portas para que um único objeto tenha inúmeras variáveis quanto a sua forma e seu significado. Levando esse fato em consideração, ainda é possível observar como a marca se posiciona e diz respeito a alguns valores sociais e culturais que são compartilhados se tomarmos como partida a ótica da autora Santaella (2003), que explicita como é construído os valores sociais e culturais a partir da mídia:

A cultura midiática propicia a circulação mais fluída e as articulações mais complexas dos níveis, gêneros, e formas de cultura, produzindo o cruzamento de suas identidades. Inseparável do crescimento acelerado das tecnologias comunicacionais, a cultura midiática é responsável pela ampliação dos mercados culturais e pela expansão e criação de novos hábitos no consumo de cultura. p. 59)

Dessa forma, a aproximação que a marca procura ter com o interlocutor está articulada nos hábitos, é conectada a fatores culturais que estimulam o interlocutor a olhar a marca como algo vivo e personificado, como a construção imagética ligada diretamente aos efeitos sonoros, por exemplo. Devemos ficar atentos ao desenvolvimento sonoro produzido durante o comercial, que se constrói a partir dos acontecimentos narrados. O fundo musical é uma ferramenta estratégica que também guia a narrativa, sendo muito importante para ajudar o interlocutor a criar uma ambiência imaginária acerca do local e do tempo, e ajuda na construção das características da personagem principal. Segundo Lemos (2002), isso é possível porque:

Os novos meios de comunicação que coletam, manipulam, estocam, simulam e transmitem os fluxos de informação criam uma nova camada que vem a se sobrepor aos fluxos materiais que estamos acostumados a perceber. O ciberespaço é um espaço sem dimensões, um espaço de informações navegável de forma instantânea e reversível. Ele é, dessa forma, um espaço mágico, caracterizado pela ubiquidade, pelo tempo real e pelo espaço não-físico. Estes elementos são característicos da magia como manipulação do mundo. (p.128)

Imersa nessa realidade teórica, a trilha sonora parte de uma narrativa informacional, já que o ciberespaço gera um sentimento fantasioso entre os indivíduos. Os novos meios de comunicação têm sua importância como um recurso estratégico, já que estas se referem à soma de novos métodos e de novas tecnologias aos canais de comunicação tradicional, contribuem diretamente para complementar a narrativa 
midiática. O objeto de estudo em questão relaciona sua narrativa intimamente com a trilha sonora, já que sua criação de expectativa para o clímax da narrativa entrelaça o visual ao sonoro para indicar e gerar intenções e sensações. Barbosa (2015) argumenta que:

Em obras de ficção tipicamente $80 \%$ do som final é criado em pósprodução incluindo diálogos, música, paisagens sonoras e efeitos especiais, o que significa que quase toda a componente sonora de uma obra de ficção não passa de uma representação virtual de fenômenos psico-acústicos que têm o objetivo de criar na audiência a ilusão de um ambiente real e credível. (p. 1)

Nesse contexto, percebemos que o storytelling faz uma corrente com todos esses artifícios em uma narração que foi totalmente produzida em uma perspectiva estratégica publicitária. Ficam claras as suas consequências e resultados diante da sua construção para a geração de sentidos provocados a partir do uso de artifícios publicitários. A nova perspectiva comunicacional permite essa ligação entre marcas e interlocutores numa lógica dentro do storytelling que:

Parte da solução para melhor compreender a Economia da Atenção aparentemente é deixar de falar no conceito de "mensagem" substituindo-o pelo de "história". Abandonar o conceito de emissor e usar o de "criador da história". Banir o "receptor" e utilizar "usuário da história". (Nuñez, 2009, p. 23)

A partir disso, fica fácil associar a Apple ao novo contexto comunicacional e em específico ao formato de divulgação da mensagem, que no caso é audiovisual. É factível que as marcas não vendem mais apenas produtos, e as pessoas não compram apenas produtos, mas sim significados (Kirppendorff, 2005; Verganti, 2009). Esses significados estão embutidos nas mensagens que a marca injeta em sua narrativa através do visual somado ao sonoro, e são decodificados no indivíduo para que ele sintetize novos signos e significados. É de suma importância validar que, para que ocorra esse processo de comunicação e a materialização da mensagem aconteça, o indivíduo precisa ter uma bagagem de conhecimento que parte da própria mensagem da narrativa. Apple, em seu comercial natalino de 2018 (da figura 1 à 5), deixa isso claro, quando traz uma realidade aplicada em uma narrativa que reproduz símbolos e valores sociais que são reais. Ainda, podemos tratar da relação direta da marca com a nova geração e as relações emocionais do consumidor, como afirmam abaixo:

O público não as vê somente como provedoras de produtos, mas como coadjuvantes em um estilo de vida. Tratando-se das novas gerações, a ligação emocional com as marcas que mostram que realmente entendem seus estilos de vida tornar-se relevante, apoiando as suas necessidades - e a autenticidade é a chave. (Szabluk, Linden e Bernardes, 2015, p. 231) 
Essa autenticidade também está presente na campanha apresentada como objeto principal deste estudo. Segundo Schallehn, Burmann e Riley (2014), a autenticidade depende de três fatores como percepção de sua individualidade, consistência com o consumidor e continuidade em se manter estável ao longo do tempo. Esses três pilares da autenticidade refletem diretamente na construção estratégica do storytelling no comercial da Apple, porque são esses fatores que unem o emocional e o subjetivo dos interlocutores, logo fortalecem laços com o público junto às características da marca, gerando experiência comunicacional.

Para Beverland (2009), as narrativas nos fazem baixar a guarda e ficar mais receptivos a novas ideias ou visões diferentes sobre algo. A justificativa para o uso do formato de storytelling no comercial da Apple não é só para conseguir levar o público até o ato da compra, mas em especial fornecer subsídios estratégicos de forma que, por meio da humanização de personagens e consequentemente da marca, retratem uma possível realidade: colocar o consumidor em contato com o produto que desencadeia uma vivência. Na nova configuração comunicacional, é factível que o próprio público consumidor também se modificou e se tornou portador de poder a partir dos meios de comunicação, porque, nessa conexão que ele possui, é possível adentrar em outros espaços, assuntos etc., que até então não eram acessíveis. Assim, agora o público pode não só pesquisar, mas também receber conteúdos que são passíveis de entendimento e crítica, pois ele consegue aprofundar melhor nas informações que estão a sua disposição na internet e nos meios de comunicação.

Percebemos que essa situação possibilita tornar o próprio público parte da narração por meio dos mecanismos sensoriais, como a geração de valores sentimentais e simbólicos associados à humanização das relações construídas ao decorrer do comercial. Para compreender melhor a produção do storytelling, também se faz necessário atentar-se para as técnicas que giram em torno do Marketing 4.0, segundo Kotler et al. (2017). A construção da geração de sentidos e significados perpassam por fatores que atualmente colaboram para atribuir uma nova ótica para a marca, como a humanização, que associa a marca a algo orgânico e vivo. Um viés para categorizar essa estratégia é a emocionalidade, que, para os referidos autores:

Marcas que evocam emoções podem induzir ações favoráveis dos consumidores. Elas se conectam com os clientes em um nível emocional com mensagens inspiradoras. Às vezes, essas marcas também se conectam com eles exibindo seu lado bem-humorado. (p. 169)

Dessa maneira, é possível verificar que a Apple busca elencar meios que giram em torno do storytelling para trazer novas características que englobem a participação cativa do interlocutor. Segundo Xavier (2015), é também dessa maneira que as marcas 
conseguem adquirir o valor de orgânicas e consequentemente vivas, porque pelo storytelling é possível redimensionar o valor da marca e adquirir novos significados que possibilitem um impacto maior ao interlocutor, colocando-o em um patamar de definidor do que a marca significa.

No resultado da pesquisa de Moreira e Fernandes (2012), a música usada nos vídeos publicitários influencia no comportamento humano, já que imagem e som destacam quando usados juntos, o que permite sincronizar tais entusiasmos. Verificamos que a trilha sonora da Apple é uma tendência comunicacional globalizada; o comercial pode ser transmitido em qualquer país que será compreendido por que utilizam de uma cultura midiática global e conseguem conectar o espectador emocionalmente. Essas estratégias emocionais abordadas anteriormente em Kotler et al. (2017) têm ligação direta com a indução emocional do homem com a música, uma vez que a indução parte da sincronização musical com as imagens, em que a marca conecta o sujeito num entendimento global e o permite a participar da mensagem, percebam que utilizam destas tendências comunicacionais assegurados pela cultura midiática globalizada, alcançando conexões emocionais nesta sincronia da trilha sonora com o comportamento e o valor humano global.

\section{Influências das mídias e das mensagens publicitárias: divulgação das grandes marcas com o storytelling}

Por último, buscamos os autores Al Ries e Jack Trout para entendermos melhor a propaganda e as influências da mídia a partir dos elementos publicitários na mensagem do storytelling. Levantamos discussões em torno dos diferenciais usados nas divulgações publicitárias para diferenciar as marcas - neste caso o comercial da Apple (2018); ao mesmo tempo, levantamos pontos do comportamento do seu público diante desses artifícios usados pela publicidade. Essa influência das marcas também contribui para a interação midiática com o consumidor a partir da produção e da distribuição no storytelling.

O storytelling da Apple foi introduzido nas redes sociais, mas não encontramos fontes seguras que afirmassem datas e se realmente foi primeiro pela rede YouTube. Portanto, não podemos assegurar a forma de divulgação nem a própria Apple informa em sua página web. Alguns sites publicam que foram fãs e outros que foram a própria Apple, mas não divulgam as fontes; apenas podemos constatar que foi no decorrer do mês de novembro de 2018, conforme a postagem dos vídeos no YouTube. Quanto ao objetivo da divulgação do vídeo, também não temos fonte segura; sabemos que, em valor de mercado, a Apple arrecadou cerca de 1 trilhão de dólares, o que mostra o crescimento da empresa, mas as fontes não explicam o que gerou tal arrecadação, já que trata das expectativas, do valor associada à marca, da disputa de mercado, 
da globalização, dos custos com campanhas publicitárias etc.; Esses fatores não permitem um resultado conclusivo quanto ao objetivo do vídeo (G1, 2018; Apple Inc, 2017), mas, se embasarmos em teoria, Prado e Prado (2009) garantem que o valor da marca é criado a partir da divulgação em longo prazo, sendo necessário uma campanha publicitária com planejamento constante, aumentando o número de vezes que o indivíduo irá receber a mensagem. Nesse sentido, esse comercial da Apple é um dos diversos comerciais lançados pela marca, baseado na associação com os novos meios de comunicação, como uso dos canais tecnológicos, neste caso o Iphone e que está presente no vídeo analisado. Ligação direta com os estudos de Cruz, Figueira e Porto (2016), os autores explicam que a divulgação adequada está nos canais distribuídos com eficácia, como vimos pelo acesso de indivíduos no canal do YouTube. São apenas algumas das novas ideias buscadas a partir do avanço tecnológico para atingir um público cada vez maior (Ahmed, Deshpande e Khode, 2014). Essa disseminação está nas ferramentas de divulgação da marca e de produtos, usadas pela propaganda para o mundo corporativo, já que um dos papéis das agências de propaganda é estimular as pessoas à compra e que as produções estão amarradas à comercialização da imagem da empresa (Lino, Palácios e Rego, 2008). Essas diversas fontes nos permitem afirmar que a propaganda usada (storytelling da Apple) está nas atividades persuasivas a partir dessas produções que informam, interagem e permitem o internauta opinar nas redes sociais.

Nas tentativas de diferenciar as marcas, uma opção é interagir com o seu público, já que a popularidade da internet e das redes sociais contribuiu ativamente para essas alterações no paradigma então vigente, possibilitando a convergência dos meios de comunicação; métodos alternativos que partem da comunicação publicitária e que geram o cenário atual reforçam a prática do uso da internet para ir além do contato comercial de venda e de compra, abrangendo valores simbólicos em que predomina uma nova fonte de poder. Segundo Kerckhove (1997):

Enquanto a TV fornecia uma espécie de espírito coletivo para toda a gente, mas sem qualquer contribuição individual, os computadores eram espíritos privados sem contribuições coletivas. A convergência de ambos oferece uma possibilidade nova, sem precedentes, a de ligar indivíduos com as suas necessidades pessoais a mentes coletivas. Esta nova situação é profundamente criadora de novos poderes; tem repercussões sociais, políticas e econômicas. Irá acelerar as mudanças e adaptações na cena geopolítica assim como na sensibilidade privada de todos. (pp. 89-90)

A partir desse estudo de Kerckhove (1997), observando o comercial da campanha natalina da Apple de 2018, é possível notar que existe uma incorporação de artifícios publicitários alternativos que são empregados ao formato de storytelling e como ocorrem adaptações e novas repercussões no mercado, notando como a 
marca reverbera social e mercadologicamente. Entretanto, surgem questionamentos acerca da construção desse formato em função da ótica publicitária, algo que nos faz buscar maiores informações sobre as reações do consumidor diante da marca.

Ao retornarmos à trilha sonora da Apple para entendermos os novos formatos de divulgação, Ries e Trout (1987) afirmam que, "de uma maneira geral, a mente só aceita aquilo que de certa forma coincide com seu conhecimento ou com sua experiência anterior. Milhões de dólares têm sido gastos na tentativa de mudar a mente através da propaganda. Uma vez que a mente esteja formada, é quase impossível modificá-la" (p. 5). A partir dessa relação estabelecida pelos autores, a marca arquiteta sua narrativa, pela utilização de elementos que já são conhecidos pelo público, mas que estão espalhados de forma desordenada na mente de cada indivíduo. A marca busca organizar esses elementos expostos pelos autores por meio dos artifícios elencados em sua narrativa, como, por exemplo, a trilha sonora, para que ocorra associações entre a bagagem dos indivíduos e a marca. Abaixo, parte das cenas do comercial da campanha natalina da Apple (figuras 6 e 7), que permitem ilustrar nossos argumentos:

Nas figuras 6 e 7, temos as influências midiáticas destacadas. Os gestos de emoção do personagem (figura 6) fazem com que o internauta se envolva com os sentimentos narrados; logo, a marca é destacada no laptop (figura 6), assim como no final do comercial temos a logomarca (figura 7) em branco bem no alto da cidade. A mensagem publicitária está nessa ligação da realidade vivenciada no período do Natal, do qual a marca Apple acompanha o indivíduo no seu cotidiano. Com as novas formas de fazer comunicação e publicidade, as marcas têm buscado contato com o público, em constante transformação, como o caso do nosso objeto de estudo.

O destaque da trilha musical nessa narrativa acontece com o intuito de propiciar um vínculo da marca com o sujeito somado ao visual, como visto nas figuras 6 e 7. A ligação da trilha sonora com a história contada no comercial resulta na presença da marca no dia a dia do indivíduo, fazendo-se presente nas soluções e nos momentos importantes desse indivíduo. Algo que tem relação direta da marca com o consumidor. Arnould e Thompson (2005) afirmam que as "ideologias de mercados de massa e estratégias interpretativas do consumidor" são base para aproximar a marca do receptor, eles estudam o consumidor enquanto receptor e produtor de significados e conteúdo. Nessa ótica, as marcas visam desenvolver a conquista do público mediante análises interpretativas e, em função disso, seus esforços comunicacionais se veem refletidos em, designs etc. diversos, a fim de argumentar por meio de significados simbólicos a conquista do público, além de praticar a construção da sua imagem. Para Boulding (1961), em seu livro The 

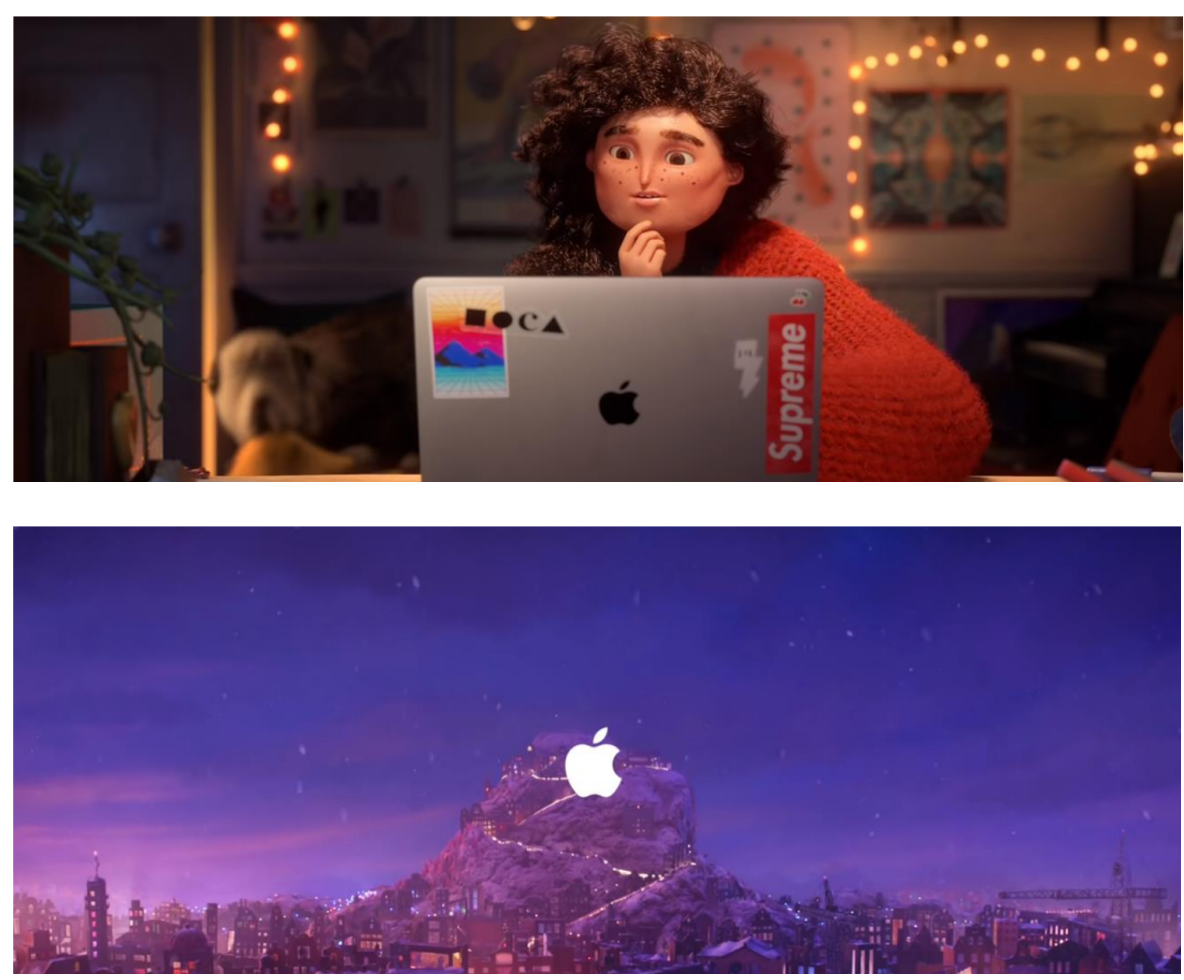

Figuras 6 e 7. Cenas do comercial da campanha natalina da Apple Share your gifts (2018)

Fonte: Trecobox. https://trecobox.com.br/2018/1 1/22/novo-comercial-de-natal-da-apple-promete-tocarseu-coracao/

image, o comportamento dos indivíduos não é pautado pelo conhecimento ou pela informação, e sim pelas imagens que ele recebe, ou seja:

Assim como os produtos, também marcas têm Imagem. Ela é a soma das impressões vividas pelo consumidor a partir de variadas fontes: da experiência real, da embalagem, da empresa proprietária da marca, de outras pessoas usuárias da marca, de como é dito na respectiva propaganda, tanto quanto do tom, do formato, da mídia, da propaganda da citada marca. (Sapiro, 1993, pp. 21-22)

Este vídeo da Apple é um grande exemplo da construção dessa imagem da marca a partir dos elementos que ela utiliza, que vão desde a embalagem dos produtos à narração, como no objeto deste estudo. Mesmo assim, devemos considerar que todas essas técnicas partem das influências publicitárias para possibilitar a marca reverberar socialmente. Boulding (1961) trata da criação da autoimagem, em que os indivíduos, desde o nascimento, passam por processos de assimilações, significações, valores etc., para a construção do próprio "eu". De acordo com 
isso e considerando o objeto de estudo, podemos afirmar que a Apple busca agir permeando entre a própria marca e o público consumidor, porque, em sua narrativa, ela simula uma realidade e elenca outros elementos, como a música, para transmitir sensações ao interlocutor. Nesse sentido, temos a materialização de uma possível imagem que seja a do público, o qual realiza uma associação quando tem contato com o conteúdo, validando o formato da mensagem que a marca apropria em função da mídia. Sapiro (1993) afirma que "um consumidor comprará um produto porque, entre outras coisas, ele sente que ele traduz sua própria autoimagem" (pp.2526). O vídeo da Apple busca a representação real do público e consequentemente levá-lo para a ação de compra. Trabalhar sua imagem junto ao mercado é uma conduta conceituada de branding. Segundo Martins (2006): "o conjunto de ações ligadas à administração das marcas, são ações que, tomadas com conhecimento e competência, levam as marcas além da sua natureza econômica, passando a fazer parte da cultura, e influenciar a vida das pessoas" (p. 6). Essa forma de gerir uma marca pode ser caracterizada como estratégia publicitária quando tomada por esse viés que busca fidelizar o consumidor. Além disso, a utilização do formato de storytelling foi focada apenas para a divulgação on-line; com isso, podemos afirmar que essas práticas estão sendo cada vez mais empregadas no intuito de encurtar a distância com o público. De acordo com Jenkins et al. (2014), a prática publicitária está se desenvolvendo levando em consideração essa mutação comunicacional, à medida que o público fica mais ativo:

As decisões que cada um de nós toma quanto a passar adiante ou não textos de mídia — quanto a tuitar ou não a última gafe de um candidato a presidente, encaminhar ou não por e-mail uma receita de biscoitinhos de Nieman Marcus, compartilhar ou não um vídeo de uma gaivota roubando uma loja - estão remodelando o próprio cenário da mídia. (p. 24)

Desse modo, ao estudarmos o storytelling como estratégia publicitária na campanha da Apple a partir dos textos midiáticos, nos permite entender diversas questões de comportamento estratégico das marcas e suas respectivas narrativas usadas nas mídias. Segundo Kotler et al. (2017), no passado as pessoas eram facilmente influenciadas pelas campanhas de marketing e de certa forma publicitárias, o que não acontece tão facilmente hoje:

As marcas não deveriam mais ver os consumidores como meros alvos. No passado, era comum as empresas transmitirem sua mensagem por diferentes mídias publicitárias. Algumas até inventavam uma diferenciação pouco autêntica para poder se destacar da multidão e dar respaldo à imagem de sua marca. Com isso, a marca costuma ser tratada como uma embalagem externa, permitindo uma representação falsa de seu verdadeiro valor. Essa abordagem não será mais eficaz, porque, com a ajuda de suas comunidades, os consumidores se defendem das marcas ruins das quais são alvos. (p. 27) 
Levando em consideração esse sistema, as grandes marcas buscam atentar-se a esses acontecimentos para traçar novos caminhos em prol de uma comunicação efetiva com o público, junto com a criação de conteúdos que estabeleçam um diálogo, e não uma comunicação com o fluxo único. Como principal objeto deste estudo, a trilha sonora musical do comercial natalino de 2018 da Apple, adotou essas práticas estratégicas e desenvolveu em cima do formato narrativo uma história que envolve uma grande produção que foge dos modelos de comerciais já conhecidos. A utilização do storytelling, que gira em torno da prática de contar histórias, se levada em consideração a tradução livre da palavra, faz a marca oferecer conteúdo potenciais de recepção para o público interlocutor, abranjam que temos influências midiáticas nestas mensagens publicitárias criadas no storytelling, como meio de divulgação da marca. Isso vai de encontro com o estudo de Donaton (2007), pois é possível observar que a marca enxerga esse momento de mudança no paradigma comunicacional, une o entretenimento ao comercial a fim de estreitar o contato com o público e, assim, afirmar-se enquanto uma marca útil, aumentando seu valor perante a própria essência da marca e o mercado.

\section{Considerações}

Verificamos, a partir dos textos de Henry Jenkins, que o comercial natalino de 2018 da Apple é produto de uma convergência midiática, uma conexão da marca com o consumidor, sendo que a trilha sonora musical utilizada interfere nos sentidos da narrativa e consequentemente provoca atenção do interlocutor. Estudo que contribui diretamente para a área da Comunicação Social, tendo o storytelling como ferramenta eficaz, no que tange ao consumidor-interlocutor e à mídia usada comercialmente, principalmente quando é agregado outros artifícios além do visual, como o sonoro - demonstrando que juntos se complementam e constroem a mensagem a partir de uma linguagem universal: a música, gerando fortes emoções no receptor e materializando de fato a mensagem. É também possível afirmar que o formato storytelling contribui diretamente para o fortalecimento da marca em prol do mercado, conforme nossa análise sobre as atitudes dos interlocutores sobre o storytelling divulgado na plataforma do YouTube, uma vez que ele reverbera socialmente a partir da mensagem e do contexto como método de discurso. Deve-se ressaltar também que a mutação do consumidor-interlocutor é a chave que liga todo o processo do fenômeno comunicacional globalizado, desde a criação da narração até sua veiculação, sendo que podemos identificar por meio dele ocorrências de significação que permeiam entre ele e a marca. René Descartes nos ajudou a entender a dinâmica dos processos de significação do indivíduo e como acontece sua condução a partir da visualização do conteúdo destacado neste estudo, nos levando a entender que o visual tratado no comercial da Apple está amarrado ao 
sonoro (trilha sonora), técnicas comunicacionais usadas nesta linguagem midiática do Storytelling. Jenkins nos permitiu refletir quanto à conexão e à convergência dos novos meios de comunicação on-line, algo presente na cultura atual, assim como Foucault (2005) e Descartes (2005) nos levam a interpretar, a partir do discurso usado nesse vídeo, como a cultura com um olhar cada vez mais global por parte das empresas busca interagir com os indivíduos nas redes ao compartilhar conhecimento de modo de vida, a partir de suas argumentações.

Esse vídeo comercial também está apoiado no contar histórias, que é uma ferramenta que permite aos consumidores ganhar voz ativa nas redes sociais, entre outros consumidores e curiosos, gerando diversas opiniões, não é o contar história que permite dar voz ativa aos consumidores e sim o fato destes indiví duos consumidores contar histórias pessoais nas redes, a partir das discussões gerados nos comentários sobre o storytelling da Apple, fazem associações dos vídeos com suas vidas pessoais, já que o vídeo tratado está divulgado em diversas redes por diversos sujeitos. Percebemos que a narrativa comercial está na relação dos consumidores e a marca a partir da trilha sonora de Billie Eilish e Finneas O'Connell, com uso apenas de um iPhone e iMac, tendo o discurso vinculado as imagens à música. O próprio título do vídeo, Share your gifts (Compartilhe seus presentes), já nos remete ao que querem e nos leva a refletir sobre os talentos, já que a ideia é compartilhar os dons individuais. O vídeo nos demonstra que a criação pode ser dividida, visto que a tecnologia pode ser um facilitador do processo criativo e da troca. Por sua vez, a animação foi realizada em maquetes com um cenário real e posteriormente aplicou-se personagens no computador; a própria produção do vídeo é algo atual e de interesse dos indivíduos que acessam as novas redes. Nossa perspectiva quanto ao objeto de estudo aqui analisado - trilha sonora, permitiu verificarmos o quanto a marca Apple, no seu comercial natalino de 2018, pretendeu estabelecer uma relação de experiência do interlocutor com a marca, ao invés do uso propriamente dito do veículo para divulgar o produto, a trilha sonora gerou interesse nos interlocutores, já que retornavam com postagem de frases sobre o vídeo na plataforma do YouTube, estavam sempre citando a música e posteriormente compartilham o vídeo da Apple, algo que gerou novas relações com outros interlocutores, consequentemente temos uma conexão emocional entre sujeito e marca, contribuindo diretamente nas relações de mercado. Como dado de relevância, podemos afirmar que a prática publicitária intervém e trabalha nesse ponto para aproximar o contato dessa relação, sendo que o uso da trilha musical interferiu diretamente na repercussão do vídeo na internet; em consequência, o consumidor passa a ser um interlocutor da marca e a portar um papel ativo não só no mercado, mas principalmente na mídia. As influências musicais estão intimamente amarradas à interação entre o sujeito e a 
marca, no que diz respeito à comunicação publicitária. É possível interpretar que a comunicação utilizou subsídios que proporcionaram um intercâmbio do real com o fictício e redirecionaram o modo de vida visado ao mercado midiático. Alcançamos que as discussões realizadas sobre o emocional estão entrelaçadas nas relações de interesses mútuos do ser humano; muitos valores sociais são globais e um único comercial pode ser transmitido em qualquer país, independentemente da língua.

A contribuição deste estudo está ancorada especialmente ao confirmar que as semelhanças e as afinidades se tornam destaque no uso das convergências midiática, associem que a mensagem publicitária ganha força com a música, e não há um storytelling sem trilha musical, garantindo a importância sonora nestas interferências dos sentidos gerados para o interlocutor. A relação entre a marca Apple e o consumidor passa a acontecer a partir do momento que ocorre interação entre as partes, pois ambos executam processos de significação e de poder simbólico ao vivenciar online momentos especiais como o Natal, a linguagem é construída em torno da música e da imagem na intenção de gerar sensações no espectador, nos levando a perceber que tal interação, entre sujeito e marca, é uma ferramenta usada na produção do Storytelling. Contudo, consideramos importante novos estudos que obtenham dados quantitativos quanto às reações do interlocutor ao ouvir a trilha sonora do storytelling, motivos de acessos destes internautas, verificar as questões relacionais e de retorno dos pontos fortes e fracos destes indivíduos, permitindo maior conhecimento sobre o storytelling e como esta ferramenta comunicacional vem sendo usada pelas marcas.

\section{Referências}

Ahmed, S., Deshpande, N. \& Khode, A. (2014). Web based targeted advertising: a study based on patent information. Procedia Economics and Finance, 11, 522, 535. https://doi.org/10.1016/ S2212-5671(14)00218-4

Apple. [Cloud]. (2018, 11 novembro). Holiday: Share Your Gifts [Video]. YouTube. https://www. youtube.com/watch?v=aMowWZHk6hY

Apple [Cloud]. (2018, 28 dezembro). Best Christmas Ads 2018. [Videol YouTube. https://www. youtube.com/watch?v=afpq-KHvo9I

Apple [Glaucione Farias]. (2018, 27 de novembro) Apple emociona designers e criativos em sua campanha de Natal. [Vídeo]. YouTube. https://www.youtube.com/watch?v=tZoZOWExdks

Arnould, E. \& Thompson, C. (2005). Consumer culture theory (CCT): Twenty Years of Research. In Journal of Consumer Research, 31(4), 868. https://doi.org/10.1086/426626

Barbosa, Á. (2015). O Som em Ficção: Cinematográfica Análise de pressupostos na criação de componentes sonoras para obras Cinematográficas. Videográficas de Ficção. Revista Educação Gráfica, 19(2), 1-14. 
Batey, M. (2010). O significado da marca: como as empresas ganham vida na mente dos consumidores. Best Business.

Bernardes, M., Linden, J. \& Szabluk, D. (2015). A Narrativa da Marca: O Storytelling como Face da Autenticidade. Educação Gráfica, 19(2), 1-14. https://www.lume.ufrgs.br/bitstream/handle/10183/148989/000978781.pdf?sequence $=1$

Beverland, M. (2009). Building Brand Authenticity: Habits of iconic brands. Palgrave Macmillan.

Billie Eilish. [Billie Eilish]. (2018, 20 de November). Come out and play (Audio) [Video] YouTube. https://www.youtube.com/watch?v=xXFdnHiGwos

Boulding, K. E. (2016, 13 - 16 September). The Image. Ann Arbor Paperback.

Cruz, S. B., Figueira, M. S. \& Porto, S. B. (2016, 13- 16 September). Gestao estrategica da crise a oportunidade. A Influência do Mix de Marketing no processo de satisfação de clientes: uma análise em uma empresa de Materiais de Construção no Município de Tabatinga/AM.

Descartes, R. (2005). Discurso do método. Porto Alegre. L\&PM.

Donaton, S. (2007). Publicidade + Entretenimento: por que estas duas Indústrias precisam se unir para garantir a sobrevivência mútua? Cultrix.

Flórez, L., Cano, S., Collazos, C. A., Benavides, F., Moreira, F. \& Fardoun, H. M. (2019). Digital transformation to support literacy teaching to deaf Children: From storytelling to digital interactive storytelling. In Telematics and Informatics, (38), 87-99. DOI: 10.1016/j.tele.2018.09.002.

Foucault, M. (2005). Arqueologia do Saber. 7 ed. Tradução Luiz F.B. Neves. Forense Universitária.

G1. (2 de agosto, 2018). Apple atinge US\$ 1 trilhão em valor de mercado: o que explica o crescimento da empresa? Globo.com. Economia: tecnologia. https://gl.globo.com/economia/tecnologia/ noticia/2018/08/02/apple-atinge-us-1-trilhao-em-valor-de-mercado-o-que-explica-o-crescimento-da-empresa.ghtml

Gomez, L., Ribas, S. \& Mateus, A. (2009). Brand DNA: The Brands Creative Revolution. Unidcom 2009. International Conference IADE Creative University. Lisboa, Portugal.

Gregolin, M. (2003). A mídia e a espetacularização da cultura. Fadisma, Educando para um futuro de oportunidades. (16), 9-19.

Jenkins, H. (2008). Cultura da convergência. Tradução: Susana Alexandria. Editora Aleph.

Jenkins, H., Green, J. \& Ford, S. (2014). Cultura da conexão. Criando valor e Significado por meio da mídia propagável. Aleph

Kerckhove, D. (1997). A Pele da Cultura. Relógio D’ Água.

Kotler, P., Kartajaya, H. \& Setiwan, I. (2017). Marketing 4.0: do tradicional ao digital. Sextante.

Lemos, A. (2002). Cibercultura, tecnologia e vida social contemporânea. Sulina.

Lemos, A. (2007). Ciberespaço e tecnologias móveis: processos de territorialização e desterritorialização da cibercultura. Sulina.

Martins, J.R. (2006). Branding: O manual para você criar, gerenciar e avaliar marcas. Global brands 
Lino, M. H., Palácios, M. \& Rego, S. (2008). Drug promotion and advertising in teaching environments: elements for debate. Interfac. Botucatu, 12 (27), 893-905. https://doi.org/10.1590/ S1414-32832008000400018

Moraes, D. (1999). O capital da mídia na lógica da globalização. Revista C. Legenda. UFF, (6), 1-8. Moreira, M. \& Fernandes, W. S. (2012). Trilha Sonora: uma análise sobre a marca Sadia. Comunicação Social. RASSIS. https://cepein.femanet.com.br/BDigital/arqTccs/0911180163.pdf

Neto, J. \& Martins, B. (2012, 7 de septiembre). Music Branding e a Influência da música no comportamento dos consumidores no ambiente comercial. Intercom. XXXV Congresso Brasileiro de Ciências da Comunicação - Fortaleza, CE, 3 a 7 set. http://www.intercom.org.br/papers/ nacionais/2012/resumos/R7-1721-1.pdf

Nuñez, A. (2009). É melhor contar tudo. Nobel.

Pombo, K. (2015, 6 de agosto). Six ways scientists can become storytellers. Elsevier. https://www. elsevier.com/connect/six-ways-scientists-can-become-storytellers-and-why-they-should

Prado, G. \& Prado, K. (2009). Um modelo de retorno sobre investimento em ações promocionais não monetárias. Revista Portuguesa e Brasileira de Gestão, 8 (4), 10 - 24. http://www.scielo.mec. pt/scielo.php?script=sci _ arttext\&pid=S1645-44642009000400003

Ries, A. \& Trout, J. (1987). Posicionamento: Como a Mídia faz sua cabeça. Pioneira.

Sapiro, A. (1993). Formação e mudança de Imagem: Uma pesquisa exploratória. FGV - Fundação Getúlio Vargas

Sobre formação e alteração da Imagem de produtos, organizações, pessoas etc. Escola de Administração de Empresas de São Paulo da fundação Getúlio Vargas. 10 - 240. http://hdl.handle. net/10438/10509

Signorelli, J. (2012). Storybranding: Creating Standout Brands Through the Power of Story. Green Leaf.

Santaella, L. (2003). Culturas e artes do pós-humano: da cultura das mídias à cibercultura. Paulus.

Schallehn, M., Burmann, C. \& Riley, N. (2014). Brand authenticity: model development and empirical testing. Journal of Product \& Brand Management, 3 (23), 192 199. DOI: 10.1108/ JPBM-06-2013-0339.

Silva, A. (2016, 7 de setembro). Mobile storytelling: Perspectivas de narrativas em mídias digitais móveis. [Potencia] XVIII Congresso de Ciências da Comunicação na Região Nordeste Caruaru: Intercom, 2016. http://www.portalintercom.org.br/anais/nordeste2016/resumos/R52-0824-. pdf

Verganti, R. (2009). Design-driven innovation: changing the rules of competition by radically innovating what things mean. Harvard Business School Press.

Xavier, A. (2015). Storytelling: Histórias que deixam marcas. 6ª Ed. Best Business. 
